\title{
Glucose intolerance after massive liver resection in man and other mammals(Abstract_要旨)
}

\section{$\operatorname{AUTHOR}(S)$ :}

Ida, Takeshi

\section{CITATION:}

Ida, Takeshi. Glucose intolerance after massive liver resection in man and other mammals. 京都大学, 1979, 医学博士

ISSUE DATE:

1979-01-23

URL:

http://hdl.handle.net/2433/222002

RIGHT: 


\section{【168】}

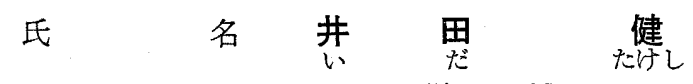

学位の種類医学 博士

学位記番号論医 博 第 768 号

学位授与の日付昭 和 54 年 1 月 23 日

学位授与の要件

学位規則第 5 条第 2 項該当

学位論文題目

Glucose intolerance after massive liver resection in man and other mammals

(人間及び動物沉括汁る肝切除の耐糖能に及ぼす影響)

論文調査委員 教授 日笠頼則 教授沼 正作 教授 戸部隆吉

\section{論文内容の要旨}

外科治療上その肝臓の機能的予備力を術前術後を通じ把握する事は大切であるが，従来の検査は主とし て肝の障害の程度をあらわして抢り再生の盛んな肝臓の予備力を見るには不充分である。そこでこの様な 観点より動物にて70\%肝切除術を施行し機能的な面より再生をとらえ臨床的応用をこころみた。

[方法]雄白色家鬼及びウィスター系雄ラットを麻醉下にて70\%肝切除術施行。家鬼，ラットにそれぞれ 経口的にブドウ糖を $2 \mathrm{~g} / \mathrm{kg}$ ・体重及び $3 \mathrm{~g} / \mathrm{kg}$ ・体重負荷(以下 OGTT と略す) し経時的に血糖值を測定。 術後経時的に残在肝のミトコンドリア（以下 $\mathrm{Mt}$ と略す）を分離調整し酸素電極並びにそれに連動する $\mathrm{pH}$ の変化より $\mathrm{Mt}$ の酸化的燐酸化能, 呼吸調節率 ( $\mathrm{RC}$ と略す), State 3 呼吸 ( $\mathrm{ST}_{3}$ と略す), P/O比を計測。 肝 Mt の呼吸酵素チトクローム $a\left(+a_{3}\right)$ は二波長分光光度計にて測定。チトクローム $a\left(+a_{3}\right)$ あたりの ATP 生成能は TN (turn-over number) で表わし式 [ATP 生成/チトクローム $\left.a\left(+a_{3}\right)\right] \times 4$ (単位： 1 /秒) にて計算。〔結果及び考按〕 $70 \%$ 肝切除家鬼に於て術後 24 時間で残在肝 $\mathrm{Mt}$ の $\mathrm{ST}_{3}$ 呼吸， RC 著明に充進，そして ATP 生成能 (TN) は術前の約160\%に増加。しかし術後48時間では肝 Mt の機能卉 進は徐々に減少し術後一週間目にほぼ正常值に回復する。そこで術後24時間目に OGTTを施行すると負 荷前血糖值は低血糖值を示すが負荷後徐々に血糖値は上昇傾向を示すものの 5 時間を経ても約 $100 \mathrm{mg} / \mathrm{dl}$ の plateau 型を示した。次に術後48時間目にOGTTを施行すると，負荷後 $3 \sim 5$ 時間経て最高血糖值よ り血糖值の浪とえど減少傾向のないlinear 型を示した。次に肝 Mt の正常化した術後一週間目にOGTT を施行すると糖負荷後 2 〜 時間目に血糖値は最高値を示しその後減少していく parabolic 型を示す。術 後四週間目も parabolic 型を示すが正常のパターンにより近ずき，六週目には正常型に回復した。一方ネ ズミにおける 70\%肝切除後の OGTT の変化をみると肝切後 3〜6時間で家鬼の 24 時間にほぼ相当する Plateau 型を示し肝切後12時間で parabolic 型に移行し術後 3 日目には正常 OGTT パターンに回復した。

以上より考它家鬼に执いて70\%肝切除を施行した場合，術後48時間までは核 DNA 合成にいたる再生初 期課程の特にエネルギーを必要とする時期で主として肝 Mt の代償性機能圥進機構により細胞内エネルギ 
一供給がなされていると考光られる。この間の OGTT パターンは plateau 型又は linear 型を示してお りこの様なパターンの時は残在肝にエネルギ一負荷が強くかかっている事が推定され術後死亡率もこの時 期に多く又この時期に他の負荷を加它ると残在肝のエネルギーバランスは容易にこわれ死亡にいたる。

OGTT で parabolic 型を示す頃になるとエネルギーバランスも回復傾向にあり動物も死亡しなくなる。 従って plateau 型やlincar 型を示す時には肝の予備力も少く注意を要するが，この時期の長さは動物種属 により異なりラットでは数時間, 家歹, 猿と長くなり人間では約 2 週前後と考えられる。この様にOGTT パターンの変化は肝切除後の機能的予備力の判定に有効であり, 一般の肝障害症例の肝予備力判定への手 がかりになるものと考吕る。

\section{論文審查の結果の要旨}

肝癌に対する外科的治療の成績は, 肝切除後に発生する肝不全の為に極めて悪い。本研究は肝切除後の 代謝動態を解析し残存肝の機能的予備力の判定と，それに対応した治療手段確立を期することを目的とし た。

肝切除患者と，実験的に肝切除を行なった家鬼を対象とした。

肝大量切除後には残存肝の energy pool 例光ば energy charge は急速に低下するが，それを回復すべ くミトコンドリアの ATP 生成能は克進する。肝切除後の肝不全は energy charge が著しく低下してい る時期に発生する。しかもこの時期には OGTT による耐糖能曲線が plateau 型または linear 型を示す。 この時期を過ぎて予備力が温存しはじめると parabolic 型に変化する。この事実より, 臨床的にも, 肝切 除術後には可及的早期に OGTTを行ない, もし parabolic 型ならば特別の治療を必要としないが, linear 型ならば侵襲を減じ，残存肝の energy charge の低下を防止する処置を積極的に行なら事が，肝大量切 除術の成績向上につながることを明らかにした。以上の研究は, 肝大量切除術後の病態解明に貢献し, 肝 癌治療に寄与する所が多い。

したがって，本諭文は医学博士の学位論文として価値あるものと認める。 